ENTREPRENEURSHIP AND SUSTAINABILITY ISSUES

ISSN 2345-0282 (online) http://jssidoi.org/jesi/

2020 Volume 8 Number 2 (December)

http://doi.org/10.9770/jesi.2020.8.2(72)
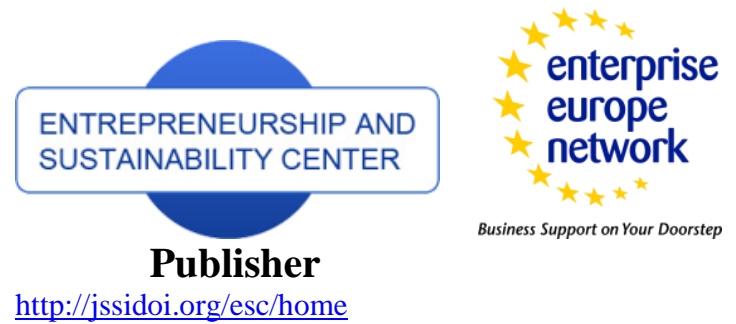

CASPA Scopus

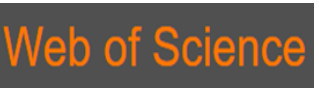

http://jssidoi.org/esc/home

\title{
MEASURING MULTIDIMENSIONAL POVERTY WITHIN THE RESOURCE-BASED APPROACH: A CASE STUDY OF LATGALE REGION, LATVIA
}

\author{
Vladimirs Mensikovs ${ }^{1}$, Irena Kokina ${ }^{2}$, Vera Komarova ${ }^{3}$, Oksana Ruza ${ }^{4}$, \\ Alina Danilevica ${ }^{5}$ \\ 1,2,3,4,5 Daugavpils University, Parades Str.1, Daugavpils, LV-5401, Latvia \\ E-mails: ${ }^{1}$ vladimirs.mensikovs@du.lv, ${ }^{2}$ irena.kokina@du.lv, ${ }^{3}$ vera.komarova@du.lv, ${ }^{4}$ oksana.ruza@du.lv, \\ 5alina.danilevica@du.lv
}

Received 18 August 2020; accepted 20 October 2020; published 30 December 2020

\begin{abstract}
In modern social science, the concept of multidimensional poverty is considered the most progressive approach to measuring poverty in countries of various development levels, including the developed ones. As an indicator of poverty in the EU, the multidimensional index of the risk of poverty and social exclusion (AROPE) is used, which integrates the indicators of income poverty, material deprivation and exclusion from the labour market. The empirical basis for its calculation is the data of the survey "Statistics of income and living conditions in the EU" (EU-SILC), published by the statistical office of the European Union. Within the framework of this article, the authors tried to contribute to the theoretical and methodological basis for studying the issue of multidimensional poverty by measuring and analysing it within the framework of the resource approach using the empirical data collected by the authors in one of the peripheral regions of Latvia - Latgale, which for many years has had the lowest indicators of economic development in the country. The resource-based approach is founded on the following methodological path: resources available for the people and households can be transformed into capital as a result of its activation and capitalization that, in its turn, can give the person socially economic benefit, i.e., a resource becomes a capital. The methodology of this study involves the application of new concepts: the "resource-poor" (few resources) and the "functional-poor" (low capitalization of available resources), as well as the "resource-functional poor", who, according to the authors, represent different target groups for the social policy, since they fundamentally differ in terms of both the causes of poverty and the approaches to supporting these groups.
\end{abstract}

Keywords: multidimensional poverty; resource-based approach; Latgale region; resource-poor; functional-poor; resource-functional poor

Reference to this paper should be made as follows: Mensikovs, V., Kokina I., Komarova, V., Ruza, O., Danilevica, A. 2020. Measuring multidimensional poverty within the resource-based approach: a case study of Latgale region, Latvia Entrepreneurship and Sustainability Issues, 8(2), 1211-1227. http://doi.org/10.9770/jesi.2020.8.2(72)

JEL Classification: $\mathrm{C} 18, \mathrm{C} 83$, I32 


\section{ENTREPRENEURSHIP AND SUSTAINABILITY ISSUES}

ISSN 2345-0282 (online) http://jssidoi.org/jesi/

2020 Volume 8 Number 2 (December)

http://doi.org/10.9770/jesi.2020.8.2(72)

Make your research more visible, join the Twitter account of ENTREPRENEURSHIP AND SUSTAINABILITY ISSUES: @Entrepr69728810

\section{Introduction}

Poverty is a multidimensional concept. A European definition was agreed first by the European Council back in 1975: "People are said to be living in poverty if their income and resources are so inadequate as to preclude them from having a standard of living considered acceptable in the society in which they live. Because of their poverty they may experience multiple disadvantages through unemployment, low income, poor housing, inadequate healthcare and barriers to lifelong learning, culture, sport and recreation. They are often excluded and marginalised from participating in activities (economic, social and cultural) that are the norm for other people and their access to fundamental rights may be restricted" (Eurostat 2013).

For quite a long time, when analysing social stratification in their countries, the researchers of the Baltic states paid great attention to the formation of the middle class, while the poor groups of the population were considered as its possible reserve, which, according to certain criteria, did not reach the role of a reliable stabilizer in conditions of complex societal transformations (Zickute 2013; Menshikov 2016; Taljūnaite, Sviklas 2018; Voronov, Ruza 2018; Swedbank 2018; Neverauskiene 2020; Kaźmierczyk 2018). However, the share of these poor groups turned out to be quite large, and after the global financial crisis in 2008 it made more than 90 percent in Latvia (Menshikov 2016). The largest gap between the candidates for the middle class and poor groups was in terms of money income, but there were also significant differences in such assessed parameters as education level and self-identification with the middle class (Menshikov 2016).

All this makes researchers to study more deeply the indeed numerous groups of poor population and propose new approaches to understanding, measuring and overcoming it. In particular, it became possible to use the concept of multidimensional poverty in the search for solutions to these problems, which has been steadily receiving much attention in scientific publications over the past decades (Betti, Verma 2008; Berenger et al. 2009; Esposito, Chiappero-Martinettix 2010; Alkire, Fang 2019; Yang et al. 2019). An initiative group of scientists from Oxford University studying poverty and human development has developed a deprivation-based Multidimensional Poverty Index (MPI), which is now widely used by international research organisations in their statistical reviews and reports (Alkire 2008, 2015; Kakwani, Silber 2008; Chakravarty et al. 2008; European Commision 2012; Alkire et al. 2017; Betti et al. 2018, OPHI, UNDP 2019, 2020). It was originally developed for India, but the analysis of the scientific literature shows that in recent years it has been calculated for many countries, including the developed ones (Betti et al. 2015; Alkire, Fang 2019; Ciani et al. 2019; Mitra, Brucker 2019). Despite its multifacetedness and topicality, the problem of multidimensional poverty is rather poorly highlighted in the Baltic states.

Within the framework of this article, the authors, firstly, will analyse the existing approaches to measuring multidimensional poverty and their results, and secondly, will try to contribute to the theoretical and methodological basis applied for studying the issues of multidimensional poverty, having measured and analysed it within the framework of the resource-based approach (Tikhonova 2006; Boronenko, Drezgic 2014) with the use of empirical data collected by the authors in one of the peripheral regions of Latvia - Latgale, which for many years has had the lowest economic development indicators in the country.

\section{Review of literature and statistics}

The authors based their analysis of scientific publications on the study of the dynamics of publishing the articles containing the term "multidimensional poverty" in their titles. The analysis of the frequency of using this term in the titles of publications indexed by the SCOPUS database showed that the interest of researchers in the problem of multidimensional poverty is growing every year, as indicated by an increase in the number of articles related to 
Make your research more visible, join the Twitter account of ENTREPRENEURSHIP AND SUSTAINABILITY ISSUES: @Entrepr69728810

this topic in the period from 2002 to 2019. During this period, a relative surge in publications related to multidimensional poverty was observed in 2008 (10 publications), having gradually peaked in 2019 (78 publications) after a five-year decline (see Figure 1).

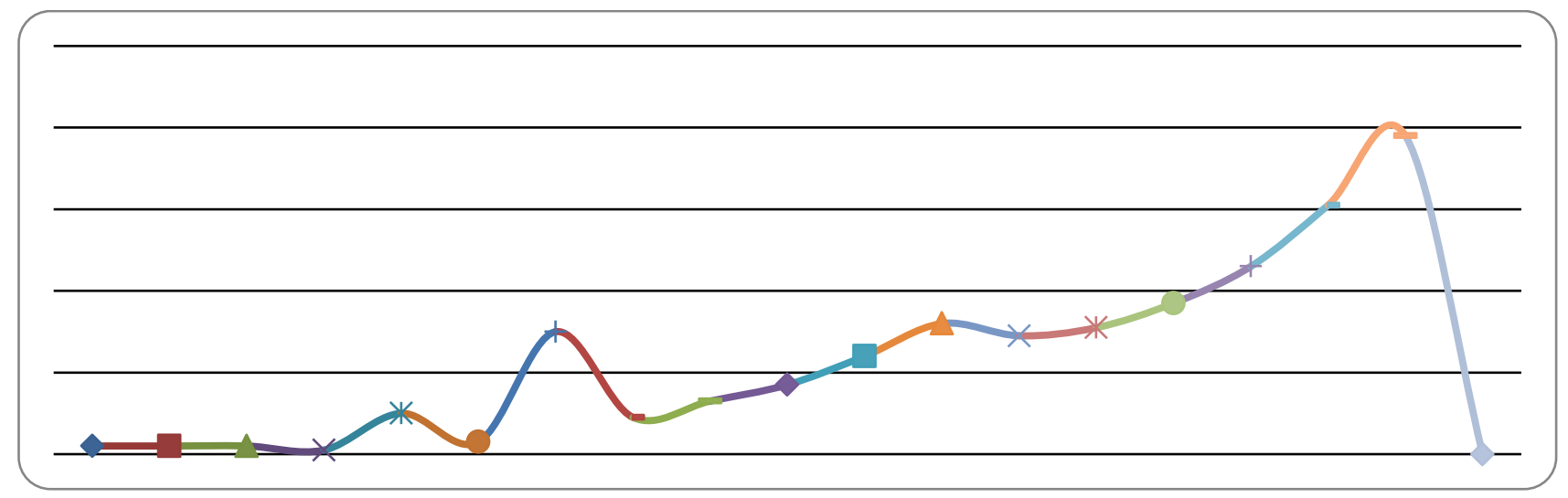

Figure 1. The number of publications related to multidimensional poverty indexed by SCOPUS, 2002-201 Source: compiled by the authors from the data of SCOPUS.

At different times, different authors have written about multidimensional poverty, and judging by the selected scientific publications, there are quite few who have dealt with this problem for at least several years (see Figure 2).

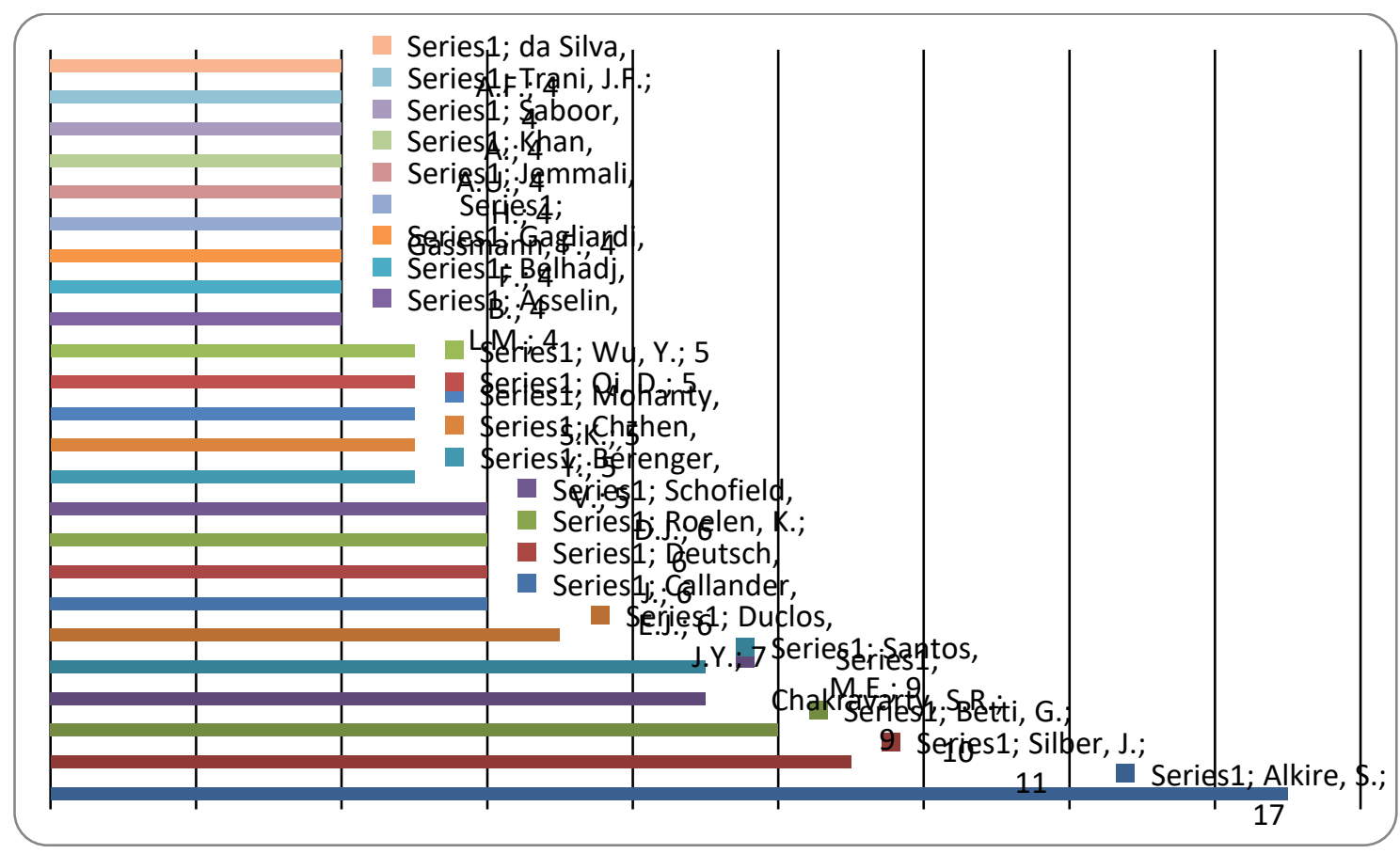

Figure 2. The number of publications related to multidimensional poverty, by authors, 2002-2019 Source: compiled by the authors from the data of SCOPUS. 


\section{ENTREPRENEURSHIP AND SUSTAINABILITY ISSUES}

ISSN 2345-0282 (online) http://jssidoi.org/jesi/

2020 Volume 8 Number 2 (December)

http://doi.org/10.9770/jesi.2020.8.2(72)

Make your research more visible, join the Twitter account of ENTREPRENEURSHIP AND SUSTAINABILITY ISSUES: @Entrepr69728810

One of the first approaches to the study of multidimensional poverty, i.e. the basic-needs strategy, was announced in August 1976 at the International Conference on Employment, organised by the International Labour Organisation (Grant 1977). Within the framework of the concept of basic needs, in addition to material needs that determine the possibility of simple physical survival, services that are necessary for the successful social activity of people are added. Measuring the level of poverty within the framework of this concept is based on the absolute poverty line, however, in addition to expenses on food, the expenses on education, leisure, and healthcare are also taken into account (Streeten et al. 1981).

The concept of basic needs was criticised by the British sociologist P. Townsend. His main argument was that despite the active debate over what to include in the set of necessary means of subsistence, the poverty line calculated on the basis of these data will not make sense, because, according to the scientist: "People will spend money on other things" (Townsend 2010). The main conclusion of P. Townsend was the formulation of the concept of poverty as a relative deprivation: people are rich or poor in relation to what share of the resources available to all members of society is available to them (Townsend 2010). To determine the extent of poverty according to this concept, the relative monetary poverty line is used, which makes $40-60 \%$ of the median income of the population of the surveyed country.

Commenting on the works of P. Townsend, A. Sen writes that although, according to P. Townsend, there is no concept of "absolute needs", and the needs of people for material goods in different societies are different, this is true only for material goods. However, the very essence of people's needs is absolute, the thing is that in different societies these needs are satisfied with the help of a different set of goods, since different societies have different capabilities. According to A. Sen, absoluteness always lies at the basis of any relativity (Sen 1983).

S. Alkire (Oxford Poverty \& Human Development Initiative, OPHI) and J. Foster (The George Washington University) have made a great contribution to the development of conceptual problems and methods for measuring multidimensional poverty. The method they have developed for measuring multidimensional poverty is called the Alkire-Foster method. This method makes it possible to determine by what parameters a certain share of the population can be considered the poor, as well as to aggregate information to reflect poverty in society (by geographic region, ethnic and other characteristics of social groups). The indicators constructed using this method allow us to identify the interconnection between the types of deprivation and can be used in the development of social policy priorities (Foster et al. 1984; Alkire, Foster 2007; Alkire 2008, 2015; Alkire et al. 2017; Samuel et al. 2018; Alkire, Fang 2019).

A great contribution to the study of multidimensional poverty was also made by the scientific publications of $\mathrm{J}$. Silber with his associates. Their articles dwell upon the study of the main challenges faced in applying a multidimensional approach to poverty and provide an overview of solutions that have not yet been proposed to address these challenges. J. Silber and his co-authors consider the main ordinal approaches to measuring multidimensional poverty (Chakravarty et al. 2008; Kakwani, Silber 2008).

In turn, G. Betii's research provides a step-by-step report on how the instruments for measuring non-monetary deprivation as well as monetary poverty can be built at the regional level. The publications by G. Betii and his colleagues present a practical methodology for estimating variance for multidimensional indicators of poverty and deprivation of households and individuals, obtained from sample surveys with complex designs and rather largesize sampling (Betti et al. 2015; Betti et al. 2018; Ciani et al. 2019) 


\section{ENTREPRENEURSHIP AND SUSTAINABILITY ISSUES}

ISSN 2345-0282 (online) http://jssidoi.org/jesi/

2020 Volume 8 Number 2 (December)

http://doi.org/10.9770/jesi.2020.8.2(72)

Make your research more visible, join the Twitter account of ENTREPRENEURSHIP AND SUSTAINABILITY ISSUES: @Entrepr69728810

Multidimensional poverty embraces aspects of human life that cannot be measured using value indicators: health, education, living conditions, personal security, enforcement of rights and opportunities, etc. A household may have an average income, though lack drinking water, lack access to quality health and education services, have no decent work, live in a region with a high crime rate and / or an environmentally unfavourable region. In this case, the person experiences deprivation - "a situation in which you do not have things or conditions that are usually considered necessary for a pleasant life" (Cambridge English Dictionary 2020).

The use of multidimensional poverty indicators in official statistics is a fairly new progressive practice. The concept of multidimensional poverty has replaced the income poverty criteria, which have been used for a long time as indicators of the socio-economic situation of citizens by the official statistical bodies of various countries, international organisations and individual researchers. Currently, the academic environment has developed an awareness that in modern economically developed societies the concept of poverty cannot be limited only to income criteria. The multidimensional approach to the definition of poverty takes into account not only the lack of financial resources of an individual, but also his limitations in access to education and healthcare, as well as difficulties associated with housing conditions, food, health and other subsistence needs.

Multi-criteria poverty index AROPE* used in European official statistics is complex and aggregates information on three poverty criteria. According to the methodology for constructing the AROPE index, persons who have at least one of the following three indicators of poverty are acknowledged to be poor (Eurostat 2020a):

- Risk of relative income poverty. The AROPE index uses the concept of relative poverty to determine the risk of income poverty. A person is considered poor if he/she lives in a household where per capita disposable income is below $60 \%$ of the median income of the country's population. The per capita disposable income of household members is calculated as follows: the monetary income of all household members, net of taxes and social security contributions, are summed up and divided by the equivalent number of household members. The equivalent number of household members is determined according to the OECD scale. According to this equivalence scale, household members are assigned weights: 1 for the first adult; 0.5 for the second and subsequent adults (aged 14 years and older); 0.3 for each child (aged 0-13).

- The presence of severe material deprivations. One is acknowledged as experiencing significant material deprivation if, due to insufficient funds, one cannot afford at least four out of the following nine points:

1) to pay off arrears of housing, utility bills, loans;

2) to have at least one week's holiday away from home annually;

3) meals containing meat, chicken, fish (or vegetarian equivalent) at least every other day;

4) home heating;

5) unexpected expenses;

6) a telephone;

7) a colour TV;

8) a washing machine;

9) a personal car.

After 2015, 4 more points were added making it total of 13 deprivations to be taken into account:

$10)$ to spend a small amount of money on oneself every week;

\footnotetext{
* At risk of poverty or social exclusion, abbreviated as AROPE, corresponds to the sum of persons who are either at risk of poverty, or

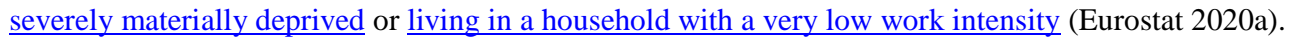


Make your research more visible, join the Twitter account of ENTREPRENEURSHIP AND SUSTAINABILITY ISSUES: @Entrepr69728810

11) to have money for regular leisure / recreation activities;

12) to pay for Internet connection;

13) to get together with friends / family at the table at least once a month.

- Exclusion from the labour market. The indicator of exclusion from the labour market reflects low work intensity of working-age people. A person is considered excluded from the labour market in the past year if the ratio of the total number of months worked by all members of his household aged 18 - 59 to the sum of all possible months of work is less than 0.2 .

For the empirical calculation of the multi-criteria poverty index AROPE, the database of the EU Statistics of Income and Living Conditions (EU-SILC) is used (Eurostat 2020b). As mentioned above, according to the AROPE methodology, three poverty criteria are determined for each individual, namely, the risk of relative income poverty, the presence of material deprivations and exclusion from the labour market. Thus, a person can be poor according to only one criterion (which is already a sufficient condition for being acknowledged as poor according to AROPE), as well as according to two or three criteria simultaneously.

Figure 3 shows the distribution of the EU population classified as poor according to various criteria of the multicriteria poverty index AROPE. The greatest contribution to the level of multidimensional poverty is made by the risk of income poverty - 73.8 million people. Meanwhile, for 47.0 million of the poor in terms of income, this risk is the only criterion of poverty, while the remaining 26.8 million, experiencing the risk of income poverty, are simultaneously poor according to one or two other criteria. 26.7 million people in the EU acknowledged to be poor are experiencing severe material deprivation and 28.2 million of the poor are excluded from the labour market. According to the AROPE methodology, the smallest part of the poor are people who are simultaneously experiencing severe material deprivation and are acknowledged to be excluded from the labour market - 1.4 million people. The number of those EU residents who are acknowledged to be poor according to all three criteria of the multi-criteria poverty index AROPE is 5.7 million people.

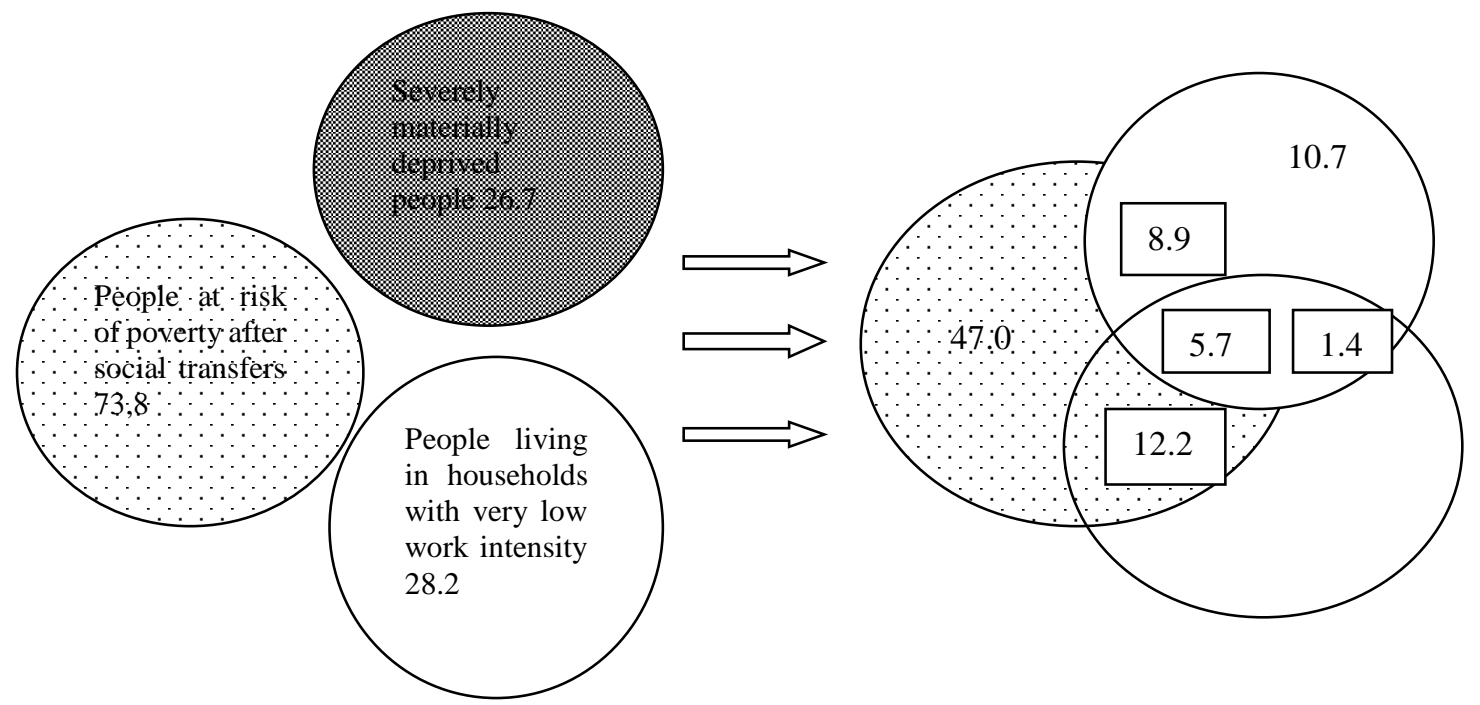

Figure 3. Aggregation of sub-indicators of "People at risk of poverty or social exclusion", total number for each sub-indicator and combination of sub-indicators (with intersections), million people, EU-27, 2018 Source: compiled by the authors from the data of European Commission 2020. 


\section{ENTREPRENEURSHIP AND SUSTAINABILITY ISSUES}

ISSN 2345-0282 (online) http://jssidoi.org/jesi/

2020 Volume 8 Number 2 (December)

http://doi.org/10.9770/jesi.2020.8.2(72)

Make your research more visible, join the Twitter account of ENTREPRENEURSHIP AND SUSTAINABILITY ISSUES: @Entrepr69728810

In 2018, 94.8 million people, or $21.6 \%$ of the EU population (without the UK), were at risk of poverty or social exclusion, a decrease of 12.5 million people, or 3 percentage points, since 2013 (European Commission 2020). The Europe 2020 strategy's goal to "lift at least 20 million people out of the risk of poverty or social exclusion" by 2020 compared with the year 2008 (European Commission 2010 (2020)) is based on the EU's composition at the time the strategy was adopted: including the United Kingdom, but excluding Croatia. In 2018, there were 108.9 million people in the EU (with the UK, but without HR) at risk of poverty or social exclusion, which is a decrease of 7.2 million people compared with 2008. It is worth noting that the EU's at-risk-of-poverty-or-social-exclusion rate increased between 2009 and 2012 because of the delayed social effects of the economic crisis, but it has been in decline since that period. However, with 12.8 million people still needing to be lifted out of the situation of being at risk of poverty or social inclusion, the EU is likely to miss its 2020 target (European Commission 2020).

In Latvia, the AROPE index has been used to measure multidimensional poverty since 2005, as part of the process of modernization of the social statistics of the European Statistical System (including the EU-SILC survey) (Central Statistical Bureau of Latvia 2018). As V. Veretjanovs, the Senior Expert of Social Statistics Methodology Section of Social Statistics Department of the Central Statistical Bureau of Latvia (EU-SILC survey manager) stated, EUSILC is based on the idea of a "common framework" in contrast with the concept of a "common survey" (Central Statistical Bureau of Latvia 2018). Some of the results of applying AROPE to measure poverty in Latvia for different age groups of the population are presented in Table 1.

Table 1. At-risk-of-poverty rate* in Latvia, \% of total population, 2004-2016

\begin{tabular}{|c|c|c|c|c|c|c|c|c|c|c|c|c|c|}
\hline $\begin{array}{l}\text { Age/ } \\
\text { year }\end{array}$ & 2004 & 2005 & 2006 & 2007 & 2008 & 2009 & 2010 & 2011 & 2012 & 2013 & 2014 & 2015 & 2016 \\
\hline $\begin{array}{l}\text { Latvia, } \\
\text { total }\end{array}$ & 19.4 & 23.5 & 21.2 & 25.9 & 26.4 & 20.9 & 19.0 & 19.2 & 19.4 & 21.2 & 22.5 & 21.8 & 22.1 \\
\hline $0-17$ & 22.0 & 25.9 & 19.8 & 23.6 & 26.3 & 26.3 & 24.7 & 24.4 & 23.4 & 24.3 & 23.2 & 18.6 & 18.4 \\
\hline $18-24$ & 16.2 & 19.2 & 15.0 & 16.2 & 19.4 & 21.0 & 22.3 & 20.1 & 19.8 & 16.9 & 22.1 & 17.3 & 16.1 \\
\hline $25-49$ & 17.3 & 18.8 & 15.7 & 17.3 & 19.1 & 19.9 & 19.3 & 18.7 & 17.4 & 17.4 & 16.0 & 14.5 & 14.6 \\
\hline $50-64$ & 21.2 & 26.3 & 23.5 & 25.4 & 23.9 & 21.0 & 20.9 & 20.1 & 20.8 & 20.5 & 21.5 & 23.1 & 22.7 \\
\hline $65+$ & 21.1 & 30.4 & 35.6 & 52.0 & 47.6 & 17.2 & 9.1 & 13.9 & 17.6 & 27.6 & 34.6 & 38.1 & 39.9 \\
\hline
\end{tabular}

Source: Central Statistical Bureau of Latvia 2018. $*$ At-risk-of-poverty rate is the monetary part of AROPE - the share of persons with an equivalised disposable income below $60 \%$ of the
national median equivalised disposable income.

As concerns material deprivations, the most common type of deprivation in general in the EU is the inability to cope with unexpected financial expenses. This deprivation was experienced by $32.5 \%$ of the population of the European Union in 2018 (Eurostat 2020c). Having analysed the data for the Baltic states, it can be noted that this deprivation was experienced most in Latvia - 55.3\% of the population, in Lithuania - 48.8\%, in Estonia - 34.7\%. This means that half of the people in Latvia and Lithuania cannot afford unexpected expenses. Another common type of deprivation is an annual week's holiday away from home. In the EU, $28.5 \%$ of the population is deprived of this opportunity, in the Baltic countries: $40.7 \%$ in Lithuania, $32.8 \%$ in Latvia, and $26.9 \%$ in Estonia. Every seventh EU resident $(8.9 \%)$ has mortgage or rent arrears, utility bills or instalment purchases, $7.3 \%$ cannot provide sufficient heating for their homes, the same number is unable to make ends meet, $7 \%$ cannot allow themselves meals with meat, chicken, fish (or the vegetarian equivalent) every other day. Having compared the Baltic countries, it can be noted that the percentage of the population experiencing all kinds of deprivation in Latvia is higher than in 
Make your research more visible, join the Twitter account of ENTREPRENEURSHIP AND SUSTAINABILITY ISSUES: @Entrepr69728810

Lithuania and Estonia. Only the percentage of deprivation of heating in Lithuania is almost 4 times higher than in Latvia, and 14 times higher than in Estonia (Eurostat 2020c).

Figure 4 shows the distribution of the Baltic states population acknowledged to be poor according to all three criteria of the multi-criteria poverty index AROPE: in 2018, there were 74 thousand such people in Lithuania, 34 thousand in Latvia, and 8 thousand in Estonia.

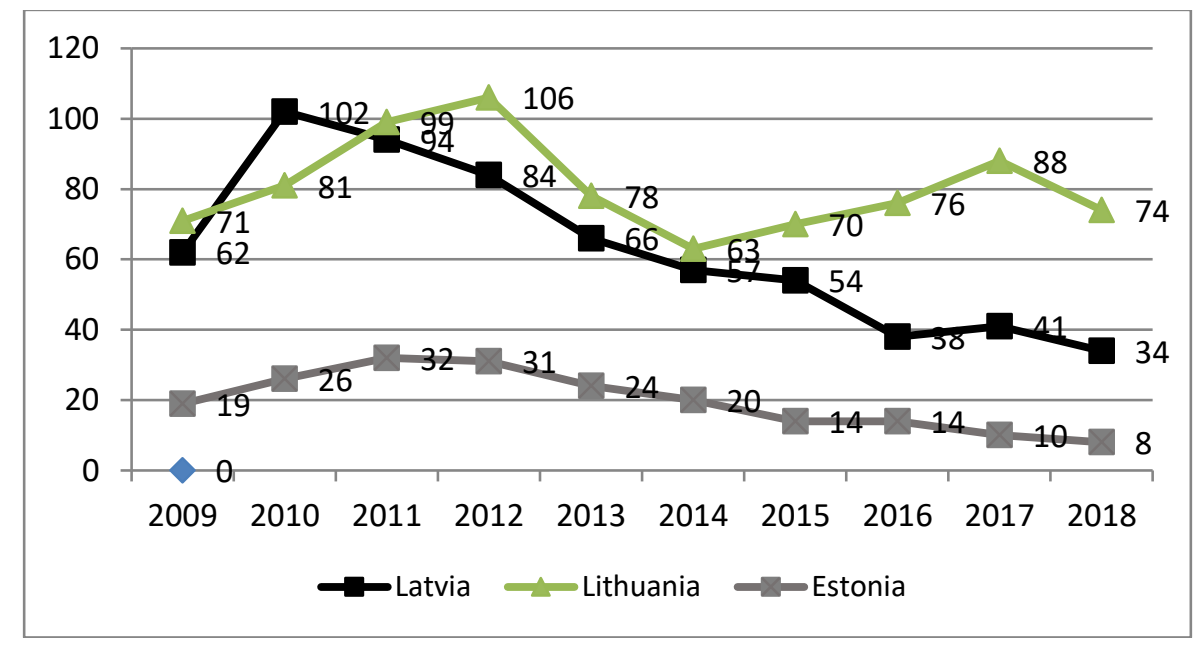

Figure 4. Baltic states population acknowledged to be poor according to all three criteria of the multi-criteria poverty index AROPE, thousand people, 2009-2018

Source: compiled by the authors from the data of Eurostat 2020c.

Thus, in Latvia and Lithuania, the level of multidimensional poverty is the highest among the Baltic states and therefore deserves special attention of researchers. As already noted in the Introduction, for the purpose of methodological testing the authors of this article will consider the case of only one peripheral region of Latvia, the poorest one during many years.

As the authors' analysis of European statistics has shown, two sub-groups of the poor population - "poor in terms of income" and "poor in terms of deprivation" - overlap less and less over time, although the situation of each of them remains rather difficult. For this reason, the use of only one of the two basic theoretical and methodological concepts for the analysis and understanding of poverty as the main one seems impossible, since it leads to the loss of a significant part of the poor population as the subject of analysis.

\section{Research methodology}

As the experts of the European Anti-Poverty Network (EAPN) state, the overall persistent high level of poverty in the EU suggest that poverty is primarily the consequence of the way society is organised and resources are allocated, whether these are financial or other resources such as access to housing, health and social services, education and other economic, social and cultural services (EAPN 2020). In this statement, the authors find support for their attempt to contribute to the theoretical and methodological basis for studying the problem of multidimensional poverty, measuring and analysing it within the resource approach (Tikhonova 2006), which is based on the following methodological path: resources available for the people and households can be transformed into capital 


\section{ENTREPRENEURSHIP AND SUSTAINABILITY ISSUES}

ISSN 2345-0282 (online) http://jssidoi.org/jesi/

2020 Volume 8 Number 2 (December)

http://doi.org/10.9770/jesi.2020.8.2(72)

Make your research more visible, join the Twitter account of ENTREPRENEURSHIP AND SUSTAINABILITY ISSUES: @Entrepr69728810

as a result of its activation and capitalisation that, in its turn, can give the person socially economic benefit, i.e., a resource becomes a capital. The application of the resource approach can be found in studies of different social sciences, sometimes revealing innovative resources or innovative forms of its activation and capitalization. One of the co-author of this article used the resource approach in her previous study, proving that economic determinants of the territory competitiveness and development sustainability is, firstly, resources availability at the territory, and, secondly, ability of the territorial agents to transform them into territory capital (Boronenko, Drezgic 2014). So, those resources which are available at the territory, but have not been transformed into territory capital, are not able to determine also competitiveness and development sustainability of this territory. V. Boronenko and S. Drezgic assume that weak development of social technologies for activation and capitalization of resources is the most important reason for hindering the competitiveness and development sustainability of Latvia's regions (Boronenko, Drezgic 2014).

In this study, the authors will try to apply a resource-based approach to measuring poverty of residents, rather than territory competitiveness and development sustainability, as it was in the above-mentioned study, using the empirical data collected by the authors in one of the peripheral regions of Latvia - Latgale.

The methodology of this study assumes the use of new concepts: "resource-poor" and "functional-poor", as well as "resource-functional poor". The first group, according to the logic of the resource-based approach, may include those people who have insufficient resources as such, whereas the second (most interesting for analysis) group includes people whose cause of poverty is not the lack of resources as such, but rather a low level of their capitalization. In turn, the third group of the poor - the "resource-functional poor" - may include those people whose lack of resources as such is accompanied by a low level of their capitalization. In theory, it is the latter type of the poor that is the most difficult target group of the social policy, most in need of support.

To measure the multidimensional poverty of residents of Latgale region of Latvia within the framework of the resource-based approach, the authors used the methodological approach to resource classification proposed by one of the authors of this article (Menshikov 2008, 2011; Meņšikovs 2009; Men'shikov, Vanags 2011), and developed a scale-questionnaire presented in Table 2.

Table 2. A scale-questionnaire for measuring poverty of the population, including questions: Which of the resources indicated in the table do you or your family possess?

Does the presence of a certain resource provide you with anything in particular?

\begin{tabular}{|l|c|c|}
\hline \multicolumn{1}{|c|}{ Resources for measuring poverty } & $\begin{array}{c}\text { I or someone from } \\
\text { my family possess it }\end{array}$ & $\begin{array}{c}\text { It brings me monetary income and / or social } \\
\text { position and / or moral satisfaction }\end{array}$ \\
\hline \multicolumn{3}{|c|}{ Economic resources } \\
\hline Immovable or movable property & 1 & 2 \\
\hline Monetary savings & 1 & 2 \\
\hline $\begin{array}{l}\text { Income: private business, salary, dividends, rental income, } \\
\text { social benefits, royalties, etc. }\end{array}$ & 1 & 2 \\
\hline & Cultural resources \\
\hline Wide knowledge & 1 & 2 \\
\hline High level of intelligence & 1 & 2 \\
\hline Foreign language skills & 1 & 2 \\
\hline & Human resources \\
\hline Higher education & 1 & 2 \\
\hline Profession & 1 & 2 \\
\hline High level of professionalism & 1 & \\
\hline
\end{tabular}




\section{ENTREPRENEURSHIP AND SUSTAINABILITY ISSUES}

ISSN 2345-0282 (online) http://jssidoi.org/jesi/ 2020 Volume 8 Number 2 (December)

http://doi.org/10.9770/jesi.2020.8.2(72)

Make your research more visible, join the Twitter account of ENTREPRENEURSHIP AND SUSTAINABILITY ISSUES: @Entrepr69728810

\begin{tabular}{|c|c|c|}
\hline \multicolumn{3}{|c|}{ Social resources } \\
\hline Favourable family environment & 1 & 2 \\
\hline Connections with influential people & 1 & 2 \\
\hline A lot of friends & 1 & 2 \\
\hline \multicolumn{3}{|c|}{ Administrative resources } \\
\hline Leadership skills & 1 & 2 \\
\hline $\begin{array}{l}\text { Responsible position (for example, at an enterprise, in a } \\
\text { state institution, etc.) }\end{array}$ & 1 & 2 \\
\hline $\begin{array}{l}\text { Work experience in the state institutions, local governments } \\
\text { or in the management of private enterprises }\end{array}$ & 1 & 2 \\
\hline \multicolumn{3}{|c|}{$\begin{array}{ll} & \\
& \text { Political resources }\end{array}$} \\
\hline $\begin{array}{l}\text { Participation in the activities of public organisations (for } \\
\text { example, a political party) }\end{array}$ & 1 & 2 \\
\hline Latvian citizenship & 1 & 2 \\
\hline Status of a deputy, a politician & 1 & 2 \\
\hline \multicolumn{3}{|c|}{ Symbolic resources } \\
\hline $\begin{array}{l}\text { Good reputation at the place of work or in the educational } \\
\text { institution }\end{array}$ & 1 & 2 \\
\hline Ability to come up with new ideas and engage others & 1 & 2 \\
\hline Popularity in your city (village, region, state) & 1 & 2 \\
\hline \multicolumn{3}{|c|}{ Physical resources } \\
\hline Good health & 1 & 2 \\
\hline Ability to overcome stress and psychological problems & 1 & 2 \\
\hline Beauty, attractive appearance & 1 & 2 \\
\hline \multicolumn{3}{|c|}{ Geographical resources } \\
\hline $\begin{array}{l}\text { Good place of residence (well-kept town or village with } \\
\text { good infrastructure - shops, transport, sports and } \\
\text { entertainment facilities, school, etc.) }\end{array}$ & 1 & 2 \\
\hline $\begin{array}{l}\text { Good demographic situation in the place of residence } \\
\text { (many married couples, many children and newborns, etc.) }\end{array}$ & 1 & 2 \\
\hline $\begin{array}{l}\text { Wide access to information in the place of residence } \\
\text { (Internet, newspapers and magazines, social events, etc.) }\end{array}$ & 1 & 2 \\
\hline
\end{tabular}

Source: compiled by the authors from the data of Menshikov 2008, 2011; Meņšikovs 2009; Men'shikov, Vanags 2011.

Based on the logic of multidimensionality and multi-criteria used by all approaches and tools for measuring poverty analysed in the previous part of the article, the authors have developed the following criteria for assigning respondents to one or another group of the poor (see Table 3). 


\section{ENTREPRENEURSHIP AND SUSTAINABILITY ISSUES}

ISSN 2345-0282 (online) http://jssidoi.org/jesi/

2020 Volume 8 Number 2 (December)

http://doi.org/10.9770/jesi.2020.8.2(72)

Make your research more visible, join the Twitter account of ENTREPRENEURSHIP AND SUSTAINABILITY ISSUES: @Entrepr69728810

Table 3. Empirical interpretation of the "resource-poor" and "functional-poor" as well as the "resource-functional poor"

\begin{tabular}{|l|l|l|l|}
\hline \multicolumn{1}{|c|}{ Criteria } & \multicolumn{1}{|c|}{ "Resource-poor" } & \multicolumn{1}{c|}{ "Functional-poor" } & "Resource-functional poor" \\
\hline $\begin{array}{l}\text { Availability of } \\
\text { resources }\end{array}$ & $\begin{array}{l}\text { Respondents who (themselves or } \\
\text { their families) possess }<17 \text { out of } \\
27, \text { i.e. }<60 \% \text {, resources }\end{array}$ & $\begin{array}{l}\text { Respondents who (themselves or } \\
\text { their families) possess } 17 \text { out of } \\
27, \text { i.e. }>60 \% \text {, resources }\end{array}$ & $\begin{array}{l}\text { Respondents who (themselves or } \\
\text { their families) possess <17 out of } \\
27, \text { i.e. }<60 \%, \text { resources }\end{array}$ \\
\hline $\begin{array}{l}\text { Level of resource } \\
\text { capitalization }\end{array}$ & $\begin{array}{l}\text { Respondents with }>60 \% \text { of their } \\
\text { available resources capitalized, } \\
\text { i.e. bringing them monetary } \\
\text { income and / or social position } \\
\text { and / or moral satisfaction }\end{array}$ & $\begin{array}{l}\text { Respondents with <60\% of their } \\
\text { available resources capitalized, i.e. } \\
\text { bringing them monetary income } \\
\text { and / or social position and / or } \\
\text { moral satisfaction }\end{array}$ & $\begin{array}{l}\text { Respondents with } \\
\text { capitalized, i.e. bringing them } \\
\text { monetary income and / or social } \\
\text { position and / or moral satisfaction }\end{array}$ \\
\hline
\end{tabular}

Source: compiled by the authors

Thus, according to the empirical interpretation proposed by the authors, the "resource-poor" are those people who have relatively few available resources (less than $60 \%$ from the list proposed in Table 2 - by analogy with the principle of relative poverty applied in AROPE (see Table 1)), but the level of their capitalization is relatively high, i.e. $>60 \%$ of the resources available to respondents or their families bring them monetary income and / or social position and / or moral satisfaction (see Table 3). In turn, the "functional-poor" are those who have less than $<60 \%$ of their available resources capitalized, i.e. bringing them monetary income and / or social position and / or moral satisfaction, despite the fact that they have relatively many resources as such, i.e. $>60 \%$ of all available resources. One and the same person can be both the "resource" and the "functional" poor (i.e. it is an "overlapping" group of "resource-functional" poverty, similarly to the criteria of the AROPE index), and also belong only to the "resourcepoor", if one has relatively few resources as such at their relatively high capitalization, or to the "functional-poor", if the resources available to a person are poorly capitalized (see Table 3). In the result of the empirical analysis the authors will obtain three target groups of the poor: "resource-poor", "functional-poor" and "resource-functional poor," whose poverty has different causes and different essence.

\section{Research results and discussion}

The basis for the empirical analysis was the data of a representative sociological survey of the population of Latgale region of Latvia, which for many years has had the lowest socio-economic development indicators in Latvia. The survey was conducted in 2017. 798 adult residents of Latgale region were interviewed, the level of education of the respondents and their nationality, as well as the type of settlement (urban or rural) were considered.

The empirical analysis of the data showed that according to the method of poverty measurement proposed by the authors, 560 out of 798 respondents or $70.2 \%$ of the adult population of the region can be classified as poor in Latgale region. The distribution of the poor by groups is shown in Figure 5. 
Make your research more visible, join the Twitter account of ENTREPRENEURSHIP AND SUSTAINABILITY ISSUES: @Entrepr69728810

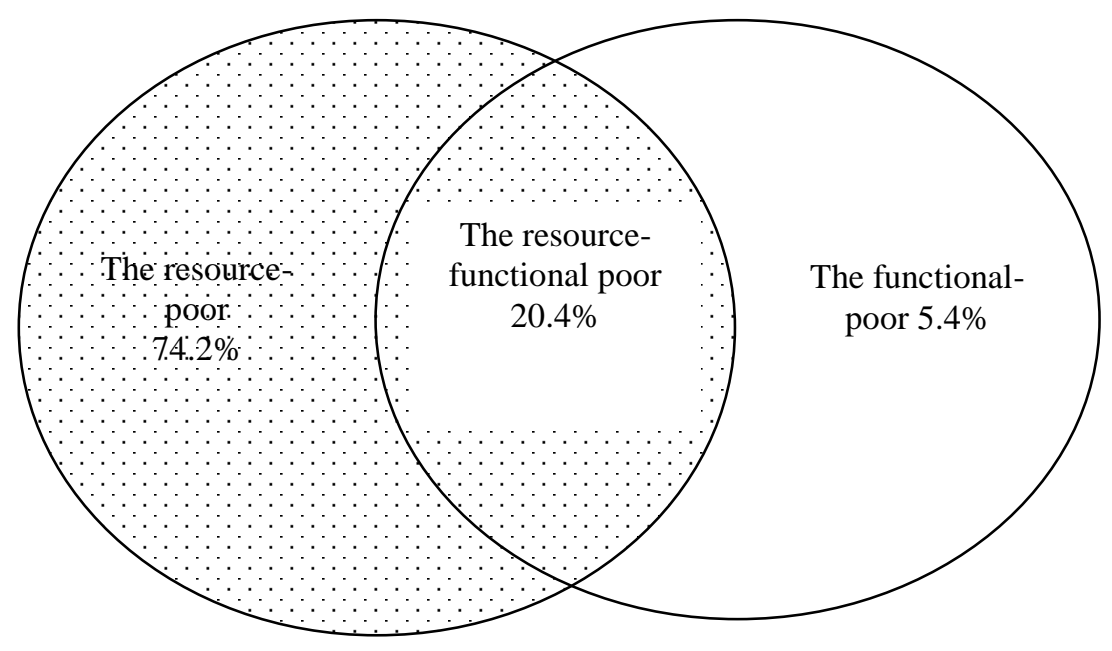

Figure 5. Share of the "resource-poor", "functional-poor" and "resource-functional poor" in the total structure of the poor, $\mathbf{n}=\mathbf{5 6 0}$ people (100\%), Latgale region of Latvia, 2017

Source: compiled by the authors according to the questionnaire results

As the data presented in Figure 5 show, the main share (74.2\%) of the poor population of Latgale region is comprised of the "resource-poor" who have at their disposal less than $60 \%$ of the resources presented for the empirical analysis. In turn, the group of the "functional-poor" constitutes a very insignificant part of the respondents acknowledged to be poor - only 5.4\%. At the same time, every fifth (20.4\%) resident of Latgale region, acknowledged to be poor, suffers from a double burden of poverty - resource (lack of resources) and functional (insufficient capitalization of scarce resources). Interestingly, approximately the same share of EU residents falls into the intersection of any two sub-indicators of the three-dimensional AROPE index (see Figure 3).

Using the correlation analysis, the authors studied the relationship between the amount of resources and the level of their capitalization. The correlation between these two indicators across the entire sampling of respondents turned out to be weak ( $\mathrm{r}=+0.201)$, though statistically significant $(\mathrm{p}=0.000$, correlation is significant at the 0.01 level (2tailed)): the more resources a person has, the higher the specific weight of their capitalization is, and vice versa. This, according to the authors, proves the real existence of the resource convertibility process discovered by $\mathrm{P}$. Burd'e (Burd'e 2001), which was studied earlier on the example of Latvia by one of the co-authors of this article (Menshikov 2008, 2011; Meņšikovs 2009; Меньшиков, Ванагс 2011). Noteworthy results are achieved by a more detailed analysis of the correlative relationship between the amount of resources and the level of their capitalization - by groups of respondents, divided according to the availability of a certain amount of resources: up to $30 \%$ of all resources presented for the analysis ("the poorest"), from 30 to $60 \%$ of resources ("not the poorest"), more than $60 \%$ of the resources ("non-poor”) (see Table 4). 


\section{ENTREPRENEURSHIP AND SUSTAINABILITY ISSUES}

ISSN 2345-0282 (online) http://jssidoi.org/jesi/

2020 Volume 8 Number 2 (December)

http://doi.org/10.9770/jesi.2020.8.2(72)

Make your research more visible, join the Twitter account of ENTREPRENEURSHIP AND SUSTAINABILITY ISSUES: @Entrepr69728810

Table 4. Correlation between the amount of resources and the level of their capitalization by groups of respondents with different amounts of resources, Pearson's correlation coefficient, $\mathrm{n}=798$ people, Latgale region of Latvia, 2017

\begin{tabular}{|c|c|c|}
\hline Group of respondents & $\begin{array}{l}\text { Correlation between the amount of } \\
\text { resources and the level of their } \\
\text { capitalization, Pearson's correlation } \\
\text { coefficient }\end{array}$ & $\begin{array}{l}\text { The statistical significance of the } \\
\text { correlative relationship, p-value }\end{array}$ \\
\hline $\begin{array}{l}\text { The "poorest" in terms of resources (less } \\
\text { than } 30 \% \text { of resources), } n=181 \text { people }\end{array}$ & +0.060 & $\begin{array}{c}0.422 \text {, the correlation is not statistically } \\
\text { significant }\end{array}$ \\
\hline $\begin{array}{l}\text { "Not the poorest" in terms of resources } \\
\text { (from } 30 \text { to } 60 \% \text { of resources), } \\
n=349 \text { people }\end{array}$ & +0.106 & $\begin{array}{l}0.048 \text {, the correlation is significant at the } \\
0.05 \text { level ( } 2 \text {-tailed) }\end{array}$ \\
\hline $\begin{array}{l}\text { "Non-poor" in terms of resources } \\
\text { (more than } 60 \% \text { of resources), } \\
n=268 \text { people }\end{array}$ & +0.079 & $\begin{array}{l}0.199, \text { the correlation is not statistically } \\
\text { significant }\end{array}$ \\
\hline
\end{tabular}

Source: compiled by the author according to the questionnaire results

As the results of a more detailed correlation analysis, presented in Table 4 show, a direct positive correlation between the amount of resources and the level of their capitalization is statistically significant only in the group of the so-called "not the poorest", i.e. in the group of those "resource-poor" who possess from 30 to $60 \%$ of all resources taken for the analysis, i.e. it is this group where the level of capitalization of resources is most correlated to their quantity: the more resources, the more successfully they are capitalized. In turn, both in the group of "the poorest" and the "non-poor", the amount of resources and the level of their capitalization are not correlated (see Table 4), i.e. it is "the poorest" and "non-poor" who are least able to extract monetary income and / or social position and / or moral satisfaction from their resources, i.e. capitalize them.

\section{Conclusions}

Having analysed the existing approaches to measuring multidimensional poverty and their results, the authors came to the conclusion that at present, the indicators of economic poverty and inequality, calculated by the Gini index, a poverty line of 1.9 USD per day, the division into poverty and extreme poverty are no longer sufficient. The empirical studies show that a decent standard of living implies that a person has access to quality education, healthcare and basic needs. By focusing on these dimensions of poverty, governments can tackle the root cause of poverty, rather than its consequences. In turn, the use of a multi-criteria index, for example, AROPE, helps to understand the component structure of poverty of vulnerable groups, which stimulates the targeting of social policy.

The analysis of the results of measuring multidimensional poverty has shown that the incidence of poverty in the EU is quite high - virtually every twentieth EU resident is poor according to this method. The level of multidimensional poverty varies greatly across the EU, largely due to differences in the socio-economic development of countries.

The authors of this article propose to measure multidimensional poverty based on the resource-based approach, identifying three typological groups of the poor: "resource-poor", "functional-poor" and "resource-functional poor". The results of the empirical analysis on the example of Latgale region of Latvia showed that the "resourcepoor" make up $74.2 \%$ of the total poor population of the region, and the "functional-poor" - 5.4\%. Every fifth 


\section{ENTREPRENEURSHIP AND SUSTAINABILITY ISSUES}

ISSN 2345-0282 (online) http://jssidoi.org/jesi/

2020 Volume 8 Number 2 (December)

http://doi.org/10.9770/jesi.2020.8.2(72)

Make your research more visible, join the Twitter account of ENTREPRENEURSHIP AND SUSTAINABILITY ISSUES: @Entrepr69728810

(20.4\%) resident of Latgale region, acknowledged to be poor, suffers from a double burden of poverty - resource and functional one.

The authors believe that resource poverty, functional poverty and resource-functional poverty represent different target areas for social policy, since they require conceptually different approaches and solutions. For example, for a group of the "resource-functional poor" it is necessary not only (if in general) to obtain resources as such, but to teach people the skills and social technologies of capitalizing their resources. Whereas the group of the "functionalpoor", due to the availability of sufficient resources, generally falls out of sight of traditional social policy and, according to the authors, is a latent form of poverty, which, if left without attention and support, eventually turns into "resource poverty" most often addressed by the state social support system.

\section{References}

Alkire, S. (2008). Choosing dimensions: The capability approach and multidimensional poverty. The Many Dimensions of Poverty, 89-119. http://doi.org/10.1057/9780230592407

Alkire, S. (2015). Global multidimensional poverty index. Pakistan Development Review, 54(4), 287-299. http://doi.org/10.30541/v54i4iiipp

Alkire, S., Apablaza, M., Chakravarty, S., Yalonetzky, G. (2017). Measuring chronic multidimensional poverty. Journal of Policy Modeling, 39(6), 983-1006. http://doi.org/10.1016/j.jpolmod.2017.05.020

Alkire, S., Fang, Y. (2019). Dynamics of Multidimensional Poverty and Uni-dimensional Income Poverty: An Evidence of Stability Analysis from China. Social Indicators Research, 142 (1), 25-64. http://doi.org/10.1007/s11205-018-1895-2

Alkire, S., Foster, J. (2007). Counting and Multidimensional Poverty Measurement. OPHI Working Paper No. 7. Oxford: University of Oxford. Retrieved July 9, 2020, from http://www.ophi.org.uk/pubs/OPHI_WP7.pdf

Berenger, V., Villarreal C.C., Celestini, F. (2009). Modelling the distribution of multidimensional poverty scores: Evidence from Mexico. Estudios Economico, 24 (1). https://doi.org/10.24201/ee.v24i1.130

Betti, G., Gagliardi, F., Verma, V. (2018). Simplified Jackknife Variance Estimates for Fuzzy Measures of Multidimensional Poverty. International Statistical Review, 86(1), 68-86. https://doi.org/10.1111/insr.12219

Betti, G., Gagliardi, F., Lemmi, A., Verma, V. (2015). Comparative measures of multidimensional deprivation in the European Union. Empirical Economics, 49(3), 1071-1100. https://doi.org/10.1007/s00181-014-0904-9

Betti G., Verma V. (2008). Fuzzy Measures of the Incidence of Relative Poverty and Deprivation: A Multi-Dimensional Perspective. Statistical Methods and Applications, 17(2), 225-250. https://doi.org/10.1007/s10260-007-0062-8

Boronenko, V., Drezgic, S. (2014). Economic determinants of territory competitiveness and development sustainability. Social Sciences Bulletin, 19 (2), 44-67. Retrieved July 17, 2020, from https://du.lv/wp-content/uploads/2016/01/SZF vestnesis 2014 2.pdf

Burd'e, P. (2001). Klinicheskaia sociologiia polia nauki. [Clinic sociology of the science field]. In Socioanaliz P'era Burd'e (pp. 5557).Moskva: Institut eksperimentalnoi sociologii.

Cambridge English Dictionary. (2020). Meaning of Deprivation in English. Retrieved June 20, 2020, from https://dictionary.cambridge.org/dictionary/english/deprivation.

Central Statistical Bureau of Latvia. (2018). Measuring poverty and inequality in Latvia: advantages of harmonizing methodology. Interregional Expert Group Meeting “Placing equality at the centre of Agenda 2030”, Santiago, Chile, June 27-28. Retrieved June 20, 2020, from https://www.cepal.org/sites/default/files/presentations/s7_2.viktorsveretjanovs_measuring_poverty_and_inequality_in_latvia.pdf. 


\section{ENTREPRENEURSHIP AND SUSTAINABILITY ISSUES}

ISSN 2345-0282 (online) http://jssidoi.org/jesi/

2020 Volume 8 Number 2 (December)

http://doi.org/10.9770/jesi.2020.8.2(72)

Make your research more visible, join the Twitter account of ENTREPRENEURSHIP AND SUSTAINABILITY ISSUES: @Entrepr69728810

Ciani, M., Gagliardi, F., Riccarelli, S., Betti, G. (2019). Fuzzy measures of multidimensional poverty in the Mediterranean area: A focus on financial dimension. Multidisciplinary Digital Publishing Institute, 11(1). https://doi.org/10.3390/su11010143

Chakravarty, S.R., Deutsch, J., Silber, J. (2008). On the Watts Multidimensional Poverty Index and its Decomposition. World Development, 36 (6), 1067-1077. https://doi.org/10.1016/j.worlddev.2007.10.003

Esposito L., Chiappero-Martinetti E. (2010). Multidimensional Poverty: Restricted and Unrestricted Hierarchy Among Poverty Dimensions. Journal of Applied Economics, 13(2), 181-204. https://doi.org/10.1016/S1514-0326(10)60009-8

EAPN (European Anti-Poverty Network). (2020). Causes of poverty and inequality. Retrieved June 30, 2020, from Internet: https://www.eapn.eu/what-is-poverty/causes-of-poverty-and-inequality/

European Commission. (2010-2020). EUROPE 2020: A Strategy for Smart, Sustainable and Inclusive Growth. Retrieved June 30, 2020, from https://eur-lex.europa.eu/LexUriServ/LexUriServ.do?uri=COM:2010:2020:FIN:EN:PDF.

European Commision. (2012). Measuring Material Deprivation in the EU: Indicators for the Whole Population and Child-Specific Indicators, 269. Luxembourg: Publications Office of the European Union.

Retrieved June 30, 2020, from Internet: https://ec.europa.eu/eurostat/documents/3888793/5853037/KS-RA-12-018-EN.PDF

European Commission. (2020). Sustainable development in the European Union Monitoring report on progress towards the SDGs in an EU context. Luxembourg: Publications Office of the European Union. Retrieved July, 2020, from Internet:

https://ec.europa.eu/eurostat/documents/3217494/11011074/KS-02-20-202-EN-N.pdf/334a8cfe-636a-bb8a-294a-73a052882f7f.

Eurostat. (2013). The measurement of poverty and social inclusion in the EU: achievements and further improvements. Seminar "The way forward in poverty measurement", December 2-4, Geneva, Switzerland. Retrieved July 2, 2020, from Internet: https://www.unece.org/fileadmin/DAM/stats/documents/ece/ces/ge.15/2013/WP_25_Eurostat_D_En.pdf

Eurostat. (2020a). Glossary: At risk of poverty or social exclusion (AROPE). Statistics Explained. Retrieved July 3, 2020, from Internet: https://ec.europa.eu/eurostat/statistics-explained/index.php/Glossary:At_risk_of_poverty_or_social_exclusion_(AROPE).

Eurostat. (2020b). EU statistics on income and living conditions (EU-SILC) methodology - Europe 2020 target on poverty and social exclusion. Statistics Explained. Retrieved July 4, 2020, from Internet: https://ec.europa.eu/eurostat/statisticsexplained/index.php/EU_statistics_on_income_and_living_conditions_(EU-SILC)_methodology_-

_Europe_2020_target_on_poverty_and_social_exclusion.

Eurostat. (2020c). Persons by risk of poverty, material deprivation, work intensity of the household, age and sex of the person intersections of Europe 2020 poverty target indicators, 2009-2018. Eurostat online data. Retrieved July 5, 2020, from Internet: http://appsso.eurostat.ec.europa.eu/nui/show.do?dataset=ilc_pees01\&lang=eng.

Foster, J., Greer, J., Thorbecke, J. (1984). A Class of Decomposable Poverty Measures. Econometric, 52(3), 761-766. https://doi.org/10.2307/1913475

Grant J. P. (1977). Employment, Growth and Basic Needs: A One-World Problem. The International "basic-needs strategy" against chronic poverty. New York: Praeger Publishers

Kakwani, N., Silber, J. (2008). Quantitative approaches to multidimensional poverty measurement. Quantitative Approaches to Multidimensional Poverty Measurement 21 February, 1-265. https://doi.org/10.1057/9780230582354

Kaźmierczyk, J. (2018). Is Neoliberalism Alive? Principles and the Washington Con-sensus. Social, Economic, and Law Research, 4 (1), 212-225. https://doi.org/10.21684/2411-7897-2018-4-1-212-225

Menshikov V. (2008). Capital in Sociological Aspect: Theoretical Bases of Investigation and Operational Parameters. In Kultura a rynek (pp. 180-186). Lublin: KUL.

Meņšikovs V. 2009. Kopkapitāls un jaunatnes dzīves stratēg̣ijas: socioloǵiskais aspekts.[Total capital and youth life strategies: sociological aspect]. Sociālo zinātņu vēstnesis, 2(9), 7-37. https://du.lv/wp-content/uploads/2016/01/SZV_2009_2.pdf. 


\section{ENTREPRENEURSHIP AND SUSTAINABILITY ISSUES}

ISSN 2345-0282 (online) http://jssidoi.org/jesi/

2020 Volume 8 Number 2 (December)

http://doi.org/10.9770/jesi.2020.8.2(72)

Make your research more visible, join the Twitter account of ENTREPRENEURSHIP AND SUSTAINABILITY ISSUES: @Entrepr69728810

Menshikov V. (2011). Human capital in the structure of total capital of personality: sociological aspect. Filosofija. Sociologija, 22(2), 150161.

Men'shikov V., Vanags E. (2011). Mezhdunarodnaya trudovaya migraciya: poisk metodologicheskih osnovanij empiricheskogoissledovaniya [International Labour Migration: Searching for Methodological Bases of Empirical Research]. Social Sciences Bulletin, 13 (2), $45-70$.

Menshikov,V. (2016). Experience of research of social classes in Latvia. Philosophy/Sociology. Vilnius: Lithuanian Academy of Sciences.

Neverauskiene, L., Danileviciene, I., Tvaronaviciene, M. (2020). Assessment of the factors influencing competitiveness fostering the country's sustainability. Economic Research-Ekonomska Istraživanja, 33(1), 1909-1924. https://doi.org/10.1080/1331677X.2020.1763821

Mitra, S., Brucker, D. (2019). Monitoring multidimensional poverty in the United States. Economics Bulletin, Access Econ, 39(2), 12721293.

OPHI (Oxford Poverty \& Human Development Initiative), UNDP (United Nations Development Programme). (2019). Global

Multidimensional Poverty Index 2019: Illuminating Inequalities. Retrieved July 15, 2020 from

http://hdr.undp.org/sites/default/files/mpi_2019_publication.pdf

OPHI (Oxford Poverty \& Human Development Initiative), UNDP (United Nations Development Programme). 2020. Charting pathways out of multidimensional poverty:Achieving the SDGs. Retrieved July 16, 2020 from

https://reliefweb.int/sites/reliefweb.int/files/resources/2020_mpi_report_en.pdf.

Samuel, K., Alkire, S., Zavaleta, D., Mills, C.; Hammock, J. (2018). Social isolation and its relationship to multidimensional poverty. Oxford Development Studie, 46(1), 83-97. https://doi.org/10.1080/13600818.2017.1311852

Sen A. (1983) Development: which way now? Economic Journal, 93 (372), 745-762. Retrieved July 17, 2020 http://darp.lse.ac.uk/PapersDB/Sen (EJ 83).pdf.

Streeten, P., Burki,.J., Haq, M., Hicks, N., Stewart, F. (1981). First Things First: Meeting Basic Human Needs in the Developing Countries. $\begin{array}{llllll}\text { Oxford University } & \text { Press. } & \text { Retrieved } & \text { July } & 16, & \text { from }\end{array}$ http://documents1.worldbank.org/curated/en/882331468179936655/pdf/997710english.pdf.

Swedbank. (2018). Middle class in the Baltics. Macro Research. Retrieved July 16, 2020 from https://www.swedbankresearch.com/english/macro_focus/2018/18-09-01/middle_class_in_the_baltics_macro_focus.pdf.

Taljūnaite, M., Sviklas, E. (2018). Middle Class in the Baltic Countries Since 1991. Social Sciences Bulletin, 27 (2), 7-27. Retrieved July 16, 2020 from https://du.lv/wp-content/uploads/2019/01/Taljunaite.pdf.

Tikhonova, N. (2006). Resource approach as a new theoretical paradigm in stratification researches. Sociological Researches, 9, $28-41$.

Townsend. P. (2010). The Meaning of Poverty. The British Journal of Sociology, 1, 85-101. https://doi.org/10.1111/j.1468-4446.2009.01241.x

Voronov, V., Ruza, O. (2018). Youth unemployment in the Latgale region of Latvia: causes and consequences. Baltic region, 10 (4), 88-102. https://doi.org/10.5922/2079-8555-2018-4-6

Yang, F., Paudel, K., Zhuang, T., Jiang, Y. (2019). Multidimensional poverty of the ethnic Tibetan farm and Herder households in Gansu province, China. Cienc. Rural, 49(8). https://doi.org/10.1590/0103-8478cr20180559

Zickute, I. (2013). Social class structure in the Baltic countries. Economics and Management, 18(1), 183-187. https://doi.org/10.5755/j01.em.18.1.4388 
Make your research more visible, join the Twitter account of ENTREPRENEURSHIP AND SUSTAINABILITY ISSUES: @Entrepr69728810

Vladimir MENSHIKOV is Dr.sc.soc., Professor at Daugavpils University. His research interests: sociology of security; regional development; capital theory. He has status of experts of the Latvian Council of Science in the fields of economics and sociology. He is a head of the Centre of Social Research in Daugavpils University, Latvia.

ORCID ID: https://orcid.org/0000-0001-9988-8588

Irēna KOKINA, Prof. Dr. psych., rector of Daugavpils University, Latvia. She has the status of Expert of the Latvian Council of Science in the fields of Psychology and of Economics and Entrepreneurship. Her research interests: sustainable development, issies of psychology and management.

ORCID ID: https://orcid.org/0000-0001-6778-0783

Vera KOMAROVA is Dr.oec., Leading Researcher at the Social Investigations Centre of Institute of Humanities and Social Sciences of Daugavpils University (Latvia). She has status of the external expert of the COST Association (Brussel). Her research interests: industrial clusters, regional economics, sustainable territory development.

ORCID ID: https://orcid.org/0000-0002-9829-622X

Oksana RUZA is Dr.oec., Docent, Researcher at the Social Investigations Centre of Institute of Humanities and Social Sciences of Daugavpils University (Latvia). Her research interests: regional economics, industrial economics, finances.

ORCID ID: https://orcid.org/0000-0002-6194-3841

Alina DANILEVICA is Dr.oec, Researcher at the Institute of Humanities and Social Sciences of Daugavpils University, Latvia. She has the status of Expert of the Latvian Council of Science in the fields of Economics and Entrepreneurship, Sociology and Social Work. She is Expert of Polish National Agency for Academic Exchange and Expert of the Foundation for Polish Science. Her research interests: regional economics, investments, sustainable development, investment climate (entrepreneurial environment).

ORCID ID: $\underline{\text { https://orcid.org/0000-0002-2749-2725 }}$

Copyright (C) 2020 by author(s) and VsI Entrepreneurship and Sustainability Center This work is licensed under the Creative Commons Attribution International License (CC BY). http://creativecommons.org/licenses/by/4.0/ 